\title{
Increasing tourism through social entrepreneurship - the case of Croatia
}

\author{
Mijana Matošević Radić*, Ivona Jukić and Antonija Roje
}

University of Split, University Department of Professional Studies, Split

\begin{tabular}{|c|c|}
\hline A B S T R A C T & ART ICLE INFO \\
\hline $\begin{array}{l}\text { Social entrepreneurship is a relatively new topic of interest within the } \\
\text { academic and the literature on it is limited. With the increase of interest in } \\
\text { recent years from various interest groups the concept of social enterprise } \\
\text { has become more widespread. The purpose of this paper is to explore the } \\
\text { link between social entrepreneurship and voluntourism, as one of the types } \\
\text { of special interest tourism. Voluntourism, according to the concept of } \\
\text { sustainable community development, relate all the stakeholders of such } \\
\text { development. Moreover, social entrepreneurship could become an } \\
\text { important vehicle for sustainable development of destinations. This paper } \\
\text { proposes that niche tourism products and more specifically, voluntourism } \\
\text { projects, under the prism of social entrepreneurship, can become the means } \\
\text { towards Croatian product diversification and long-term environmental, } \\
\text { social and economic sustainability. Quantitative research was conducted } \\
\text { and the methodology entails a case study approach. Results indicate that } \\
\text { there are limited number of projects concerning social entrepreneurship in } \\
\text { voluntourism in Croatia and also that discussed projects are not } \\
\text { recognized. This study assessed the situation in Croatia and although it } \\
\text { was comprehensive under conditions of limited data availability, it cannot } \\
\text { speak to social entrepreneurship in voluntourism globally, but it can offer } \\
\text { foundation for future research in this area. }\end{array}$ & $\begin{array}{l}\text { Keywords: social } \\
\text { entrepreneurship, } \\
\text { voluntourism, sustainability, } \\
\text { case of Croatia } \\
\text { *Corresponding author: } \\
\text { mijana@oss.unist.hr } \\
\text { Article history: } \\
\text { Received } 15012020 \\
\text { Revised } 10022020 \\
\text { Accepted } 22032020 \\
\text { This article was presented at } \\
\text { the 8th International OFEL } \\
\text { Conference on Governance, } \\
\text { Management and } \\
\text { Entrepreneurship. From } \\
\text { Corporations to Social } \\
\text { Entrepreneurs: } \\
\text { Exploring the Different } \\
\text { Faces of Social Innovation } \\
\text { (April 17th - 18th, 2020, } \\
\text { Dubrovnik, Croatia, } \\
\text { Governance Research and } \\
\text { Development Centre } \\
\text { CIRU), Zagreb, pp. 79-90 }\end{array}$ \\
\hline
\end{tabular}

\section{INTRODUCTION}

Social entrepreneurship incorporates innovative thinking and creative conceptualization to spread improvements in a social context, in contrast to individual entrepreneurship. Still, it is a relatively new topic of interest within the academic and the literature on it is limited. This paper tries to explain the relationship between social entrepreneurship and voluntourism, as one of the types of special interest tourism, and their mutual impact on sustainable community development. This is accomplished through a critical analysis of the literature on social entrepreneurship in order to understand the possible link with voluntourism and community development and also to examine the Croatian context in this matter. 
In other words, this paper proposes that niche tourism products and more specifically, voluntourism projects, under the prism of social entrepreneurship, can become the means towards Croatian product diversification and long-term environmental, social and economic sustainability. Quantitative research was conducted and the methodology entails a case study approach that includes a thorough review of the related literature and of any existing Croatian sources of social entrepreneurship in voluntourism projects to determine the state of the Croatian industry in this regard. To illustrate how social entrepreneurship along with voluntourism practice can encourage sustainable development of local community, a conceptual framework integrating the mentioned concepts is proposed.

\section{SOCIAL ENTREPRENEURSHIP AND SOCIAL ENTREPRENEUR}

During the last fifteen years, there is a growing acknowledgement of social entrepreneurship, and social enterprises in particular, on a local, national and international level, in comparison to previous decades where the concepts were less discussed (Defourny and Nyssens, 2010). According to research presented by Weerawardena and Mort (2006) there is a plethora of definitions and interpretations around the term social entrepreneurship. Some authors speculate that social entrepreneurship is only an idea of solving social problems using business methods (Peredo and McLean, 2006; Austin et al., 2006), while others believe that social entrepreneurship is just a nonprofit activity (Williams and K'nife, 2012). Dacin et al. (2010) counted 37 definitions of social entrepreneurship or social entrepreneurs, while Bacq and Janssen (2011) noted 17 different definitions of "social entrepreneurs", 12 definitions of "social entrepreneurship" and 18 definitions of "social enterprise", "social entrepreneurial venture” or "social entrepreneurship organization”.

According to Mort et al. (2003), social entrepreneurship is a multidimensional construct involving the expression of entrepreneurially virtuous behavior to achieve the social mission, a coherent unity of purpose and action in the face of moral complexity, the ability to recognize social value-creating opportunities and key decision-making characteristics of innovativeness, proactiveness and risktaking. Mair and Marti (2006) define social entrepreneurship as a process consisting of the innovative use and combination of resources to explore and exploit opportunities, that aims at catalyzing social change by catering to basic human needs in a sustainable manner. Austin et al. (2006) view social entrepreneurship as an innovative, social value creating activity that can occur within or across the nonprofit, business, or government sectors. Zahra et al. (2009) suggest that social entrepreneurship encompasses activities and processes undertaken to discover, define, and exploit opportunities in order to enhance social wealth by creating new ventures or managing existing organizations in an innovative manner. Dees (1998) proposed three dimensions of social entrepreneurship: (1) sociability: solving a social problem and creating social value; (2) innovation: being innovative, breaking patterns and changing systems; (3) market orientation: being entrepreneurial, taking advantage of opportunities, accepting risks, being resourceful, and practicing leveraging.

PAGE 26| Journal of Corporate Governance, Insurance, and Risk Management | 2020, VOL. 7, Series. 1 
Finally, for the purpose of our research we will use the definition by the Organization for Economic Cooperation and Development (OECD). OECD describe the term social entrepreneurship as the entrepreneurship that has as main goal to address pressing social challenges and meet social needs in an innovative way while serving the general interest and common good for the benefit of the community. In a nutshell, social entrepreneurship targets to social impact primarily rather than profit maximization in their effort to reach the most vulnerable groups and to contribute to inclusive and sustainable growth.

Authors including Dees (1998), Light (2006), Mair and Martí (2006), and Martin and Osberg (2007) concluded in their papers that all definitions of social entrepreneurship focus on four key factors: first one is the characteristics of individual social entrepreneurs, second one is their operating sector, third one is the resources used by social entrepreneurs, and the last fourth one is the primary mission and outcomes associated with the social entrepreneur.

One of the most commonly used definitions about social entrepreneur was provided by Dees (1998). Dess (1998) define social entrepreneurs as change agents in the social sector. Social entrepreneur by Dess (1998) is someone who plays the role of change agents in the social sector by: (1) adopting a mission to create and sustain social value (not just private value); (2) recognizing and relentlessly pursuing new opportunities to serve that mission; (3) engaging in a process of continuous innovation, adaptation, and learning; (4) acting boldly without being limited by resources currently in hand, and (5) exhibiting a heightened sense of accountability to the constituencies served and for the outcomes created. Brinckerhoff (2000) defines social entrepreneurs as those, who: (1) are willing to take reasonable risk on behalf of the people that their organization serves; (2) are constantly looking for new ways to serve their constituencies and add value to existing services; (3) understand that all resource allocations are really stewardship investments; (4) always keep mission first, but know that without money, there is no mission output. According to the Dess (2008) and Brinckerhoff (2000) literature review, about social entrepreneur we find out these three components in common: (1) entrepreneurship spirit; (2) personality and (3) social value.

\subsection{Social entrepreneurship in Croatia}

Social entrepreneurship in Croatia is a rather new phenomenon and is still poorly developed. The term appeared in the public discourse rather late, in 2006, and since then has increased to the point where a strategy for social entrepreneurship has been initiated. In April 2015 Croatia adopted a Strategy for Social Entrepreneurship Development in the Republic of Croatia for the period 20152020, which introduced a new definition of social enterprise. In the document social entrepreneurship is defined as: business based on the principles of social, environmental and economic sustainability, in which generated profit is entirely or largely reinvested for the benefit of the community. Today, almost five years after the adoption of the Strategy we can conclude that theory has not been followed by practical implementation. The present state of the development of the social entrepreneurship in 
Croatia is reflected in the passive approach towards meeting the Strategy objectives, the lack of institutional infrastructure and legal framework, and the lack of long-term financial support that would ensure stability and planned development of the sector (Šimleša et al., 2019).

Even if social entrepreneurship in Croatia is still in its early stage of development, it is dominantly generated by the associations, particularly since 2014 when new legislation (Law on Associations, Official Gazette 70/2014) opened that sector for commercial activities, with the social aspect being the dominant one. The number of social entrepreneurship actors is shown in the table below, along with their distribution according to their legal status.

It is evident from Table 1. that the number of Social entrepreneurship actors in Croatia is growing, especially among associations and cooperatives (Šimleša, Puđak and Bušljeta Tonković, 2019). Still, scientific institutions in Croatia1have to support more development of education and awareness of social entrepreneurship.

Having taken into consideration the fact that there is small number of empirical research in social entrepreneurship in Croatia, we decided to conduct one to explore the link between social entrepreneurship and voluntourism, as one of the types of special interest tourism, and to examine the Croatian context in this regard.

Table 1. Social entrepreneurship actors (2013, 2014, 2015)

\begin{tabular}{|c|c|c|c|}
\hline Legal entity & $\mathbf{2 0 1 3 .}$ & $\mathbf{2 0 1 4 .}$ & $\mathbf{2 0 1 5 .}$ \\
\hline Associations & 45 & 44 & 39 \\
\hline Cooperatives & 36 & 13 & 15 \\
\hline Companies & 13 & 2 & 1 \\
\hline Institutions & 1 & 90 & 112 \\
\hline Total & 95 & 31 & \\
\hline
\end{tabular}

\section{SUSTAINABLE TOURISM DEVELOPMENT}

Tourism, as one of the most significant phenomena of modern society, is at the same time one of the world's largest industries and hence the main form of global economic expansion (Fletcher et al., 2019). According to UNWTO (2019), the tourism industry is forecasted to continue to grow dramatically in the future based on the development aspirations of many low- and high-income countries alike. However, despite the fact that tourism is recognized as a vital contributor to job and

\footnotetext{
1 Scientific institutions in Croatia that supported development of social entrepreneurship are: Faculty of Law, University of Zagreb - the Chair of Social Policy; Faculty of Economics, University of Osijek; University of Applied Sciences VERN in Zagreb; Zagreb School of Economics and Management; and Faculty of Economics and Tourism "Dr. Mijo Mirković" in Pula (EMS, 2014).
}

PAGE 28| Journal of Corporate Governance, Insurance, and Risk Management | 2020, VOL. 7, Series. 1 
wealth creation, economic growth, environmental protection and poverty alleviation, its negative effects at a social, environmental and economic level are increasingly emphasized. This is the reason why the tourism industry should be paid attention in order to ensure sustainable development.

The most commonly cited definition of sustainable development, which is often transmitted to the sustainable development of tourism, presupposes development that meets the needs of the present without compromising the ability of future generations to meet their own needs. UNEP \& WTO (2005) defined sustainable tourism more precisely as tourism that take full account of its current and future economic, social and environmental impacts, addressing the needs of visitors, the industry, the environment and the host communities.

The fragmented nature of the tourism industry requires necessity of coordination and collaboration of many different stakeholders that have interests in the process of tourism development. The stakeholder in the tourism industry is implied as anyone who is impacted on by development positively or negatively, and as a result it reduces potential conflict between the tourists and host community by involving the latter in shaping the way in which tourism develops (Aas et al., 2005). According to Heitmann (2010), stakeholders fall into different categories depending on their levels of interest and their potential to influence in the decision-making process of the tourism destination.

It seems that local community is the main stakeholder in the sustainable tourism development process. The full involvement of local communities in the tourism sector, not only benefits them and the environment in general, but also improves the quality of the tourism experience. Local communities benefit from sustainable tourism through economic development, job creation, and infrastructure development. Tourism revenues bring economic growth and prosperity to attractive tourist destinations which can raise the standard of living in destination communities. Increase in tourism revenue to a destination acts as a driver for the development of increased infrastructure. As tourist demands increase in a destination, a more robust infrastructure is needed to support the needs of both the tourism industry and the local community. Projects imposed from outside and motivated by the pursuit of rapid economic growth often override local needs, conditions and resources, and result in unacceptable environmental, social and cultural costs (Kilipiris, 2005).

However, a variety of stakeholders can and should play the role in the development and implementation of sustainable development in the tourism sector. The private sector is responsible for producing and sustaining quality tourism products and services such as accommodation, food and beverages, local tours, transportation facilities, and recreational activities (Turker et al., 2016). It is the bearer of tourism development in general, so it wouldn't be possible to develop sustainable tourism without it.

Governments of the states which determine the rules of conduct by law are the most important in shaping sustainable tourism policy (Nsizwazikhona et al., 2015). It should be noted the influence of government institutions on change encouraging through incentives such as tax breaks or changes in the legal framework. But, a primary challenge for local governance both today and in decades ahead, is to PAGE 29| Journal of Corporate Governance, Insurance, and Risk Management | 2020, VOL. 7, Series. 1 
steer increasingly external, global forces on local development so that development achieves the shared vision of the local population. However, if tourism development by the government of a particular destination is not aligned with the wishes and needs of the local population by legal and other regulations, it is possible to expect the local population's resistance to tourism development.

Also, non-governmental organizations are one of the stakeholders in supporting sustainable tourism development. They can be involved in the provision of consultancy services in designing campaigns, investment projects or gaining public support for a series of particular causes (Iorgulescu et al., 2005).

\section{VOLUNTOURISM - A SUSTAINABLE FORM OF TOURISM}

On the global scale, voluntourism is one of the fastest growing examples of alternative travel experiences that respects dimensions of sustainable tourism. Voluntourism can be viewed as a development strategy leading to sustainable development through balance between natural resource qualities, local community and the visitor that all benefit from tourism activity (Butcher et al., 2010).

Voluntourism can be considered as an integrated organized combination of volunteer service at tourist destination and specific tourism activities, which are performed in one's spare time, out of a place of residence, in home country or abroad and that is beneficial not only for voluntourists, but also for local communities and the environment (Pompurová et al., 2018). The volunteer tourist pays for the costs of his travel and stay in the destination and moreover the fee for the opportunity to be involved in project. Unlike volunteers who participate in volunteer projects in their local communities, volunteer tourists leave a mark in communities that are often far from their homes, they work in an unfamiliar environment that involves new people, unknown or lesser-known cultures, a different tradition and different living conditions. Volunteer tourists through well-organized volunteer programs help to provide basic services that are lacking or not sufficiently available in the local community, mobilize people and influence changes and attitudes in areas such as environmental protection or sustainable consumption, and strengthen capacities by transferring knowledge and experience.

The direct benefits of the local community are reflected in the increased manpower engaged on programs that aims the needs of the community itself, as well as direct financial support through placements, while the indirect benefits include increased local employment and improved quality of public facilities and infrastructure (Morgan, 2012). Volunteering helps to activate local communities by involving people in the planning and implementation of sustainable development goals, but also contributes to the local economy as volunteers spend part of their time getting to know the area they are in.

Volunteering also provides new opportunities for tourism companies. The development of voluntourism creates the need for partnerships beyond the traditional tourist supply chain participants (i.e. accommodation providers, airline companies etc). We need to emphasize the important role of tour operators and travel agencies that offer travelers an opportunity to participate in an optional PAGE 30| Journal of Corporate Governance, Insurance, and Risk Management | 2020, VOL. 7, Series. 1 
excursion that has a volunteer component, as well as cultural exchange with locals (Wearing, et al., 2013). On the other side they should actively participate, in partnership with local NGOs, not only in promotion and distribution, but also in creating volunteer products. It allows them to stay in touch with large segment of voluntourist consumers while also enable them that both the local community and their customers recognize them as a company that is active in the area of corporate social responsibility. However, because of commercial component of volunteer programs, the critiques of voluntourism often arise, aimed not only at exploiting the local population for the purpose of achieving personal goals through short-term tourism-motivated engagement, but also at targeting profit rather than community well-being (Verardi, 2013).

Conducted research in the field of voluntourism mostly investigate environmental, humanitarian and development projects in less developed countries, whose cultures are significantly different from voluntourists' cultures. However, the perception of voluntourism as a combination of travel and volunteering only in developing countries is short-sighted and too simplistic owing to the diverse array of opportunities available in today's market (Pompurová et al., 2018). Voluntourism projects in developed countries are becoming more and more popular. They create opportunities for collaboration of different stakeholders in the local community, and they can include different segments: teaching, conservation, preserving tradition, protection of cultural heritage, research etc.

\subsection{Tourism social entrepreneurship - support for the development of voluntourism}

For the successful development of any tourism product, it is necessary to understand its complex structure. Kotler (2001) defined a product as any offering that can satisfy a need or want, such as one of the 10 basic offerings of goods, services, experiences, events, persons, places, properties, organizations, information, and ideas. Applying this concept to a tourism product, it can be differentiated as: material products (guides, maps, souvenirs), services (transport, gastronomy, recreational services etc.), local tourism facilities (castles, churches, monuments, museums, recreational centers), events (exhibitions, cultural events, sports championships, even sightseeing with a guide), personalities and groupings (i.e. famous residents or their birthplaces, characteristic ethnic groups, artists), thematic trails (walking, cycling, water trails), places (viewpoints, national parks, landscapes) and finally “ideas” (exploring the cultures of other nations, living and resting closer to nature). All these product categories are destination related and they jointly connect to create the complex final product (Lipianin-Zontek, et al., 2017).

The biggest challenge in developing a tourism product stems from the fact that some different enterprises are responsible for each component of a complex tourism product, giving tourism enterprises a critical role in delivering desired community development outcomes. Since the implementation of the traditional profit-oriented approach to entrepreneurship in tourism has shown numerous negative effects on the local community and the environment, the pursue of new social values and inducing societal transformation at large, leads to the development of the concept of social 
entrepreneurship and its application in tourism. Since social entrepreneurship is designed to facilitate social value creation, social innovation and sustainability, the tourism industry is a rich ground for social entrepreneurs (Aquino et al., 2018). This is especially true for niches such as voluntourism, social tourism or cultural heritage tourism, that are the result of the vision to foster innovative and, more importantly, sustainable tourism practices that balance the economic, social, cultural and environmental outcomes for local communities.

Social tourism entrepreneurs are defined as those who conduct tourism business activities that inspire and encourage local communities to participate in carrying out business activities travel. Here there is a strong effort from one to change himself and others by doing tourism business activities (Reindrawati, 2018). It is represented by the establishment of the innovative environment, which ensures tourism entrepreneurial projects that do not present value added only for the tourist, but also for all the local stakeholders (Alkier et al., 2017).

Due to the complex structure of the tourist product and the specific way of selling it on the market, implementation of social entrepreneurship in tourism requires social enterprises that offer a variety of products and services while also implementing social innovation strategies. Day and Mody (2017) categorize tourism social enterprises into three types based on enterprises' functions, roles, contributions and product offerings within the tourism value chain. The first type relates to a "suppliers to the tourism experience" and it includes tourism social enterprises that offer tangible products (e.g. food, souvenirs) to tourists. Often, this type adopts a social innovation where technical expertise is transferred to community beneficiaries in order to develop the local skills and knowledge to produce such goods.

The second type includes a "providers of the tourism experience", respectively social entrepreneurs which organize and involve the wider community, identify community needs, and develop local capacity to address these needs through human resource development and tourism training. And the last type refers to an "intermediaries of the tourism experience”. They involve travelmarket intermediaries (e.g. travel agencies) which sell sustainable tourism products and thus promote and educate travelers in more responsible tourism practices, emphasize the need to change travel behavior, and support social causes at the respective destinations they 'sell'. These social enterprises exist to influence public views on social issues through their commercial activities (Aquino et al., 2018).

From the above, it is evident that the opportunities for the implementation of social entrepreneurship in tourism are huge, so different local communities can cherish different examples of social entrepreneurs who contribute to the development of tourism products each in their own way, but also different forms of collaboration with other stakeholders in the community. In that regard, the conceptual framework proposed in this paper is developed from the described concepts of sustainable community development, social entrepreneurship and voluntourism, as shown in Figure 1. 


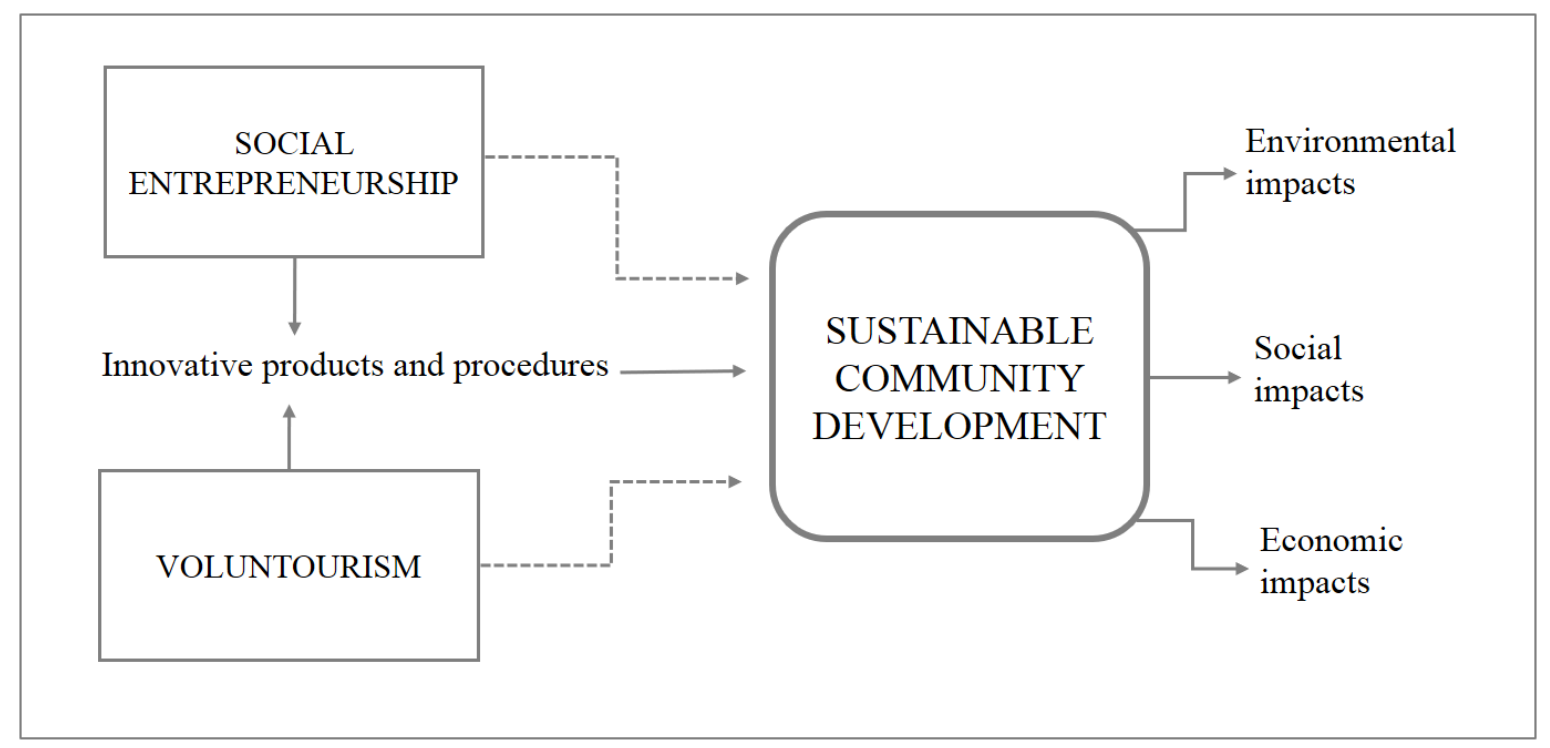

Figure 1. Social entrepreneurship and voluntourism impact on sustainable community development: A conceptual framework proposition

\subsection{The role of social entrepreneurs in the development of volunteerism: The case of Croatia}

Croatia has been an unavoidable tourist destination for many travelers from all over the world in recent years. This is evidenced by data from the Croatian Bureau of Statistics (2019), which registered nearly 90 million overnight stays in 2018. However, the data also show that more than $85 \%$ of the total overnight stays were realized in the four months of the peak season. This indicates that the dominant model of tourism development is still summer bathing tourism with marked mass characteristics. Considering all the negative effects arising from the development of this tourism model, it is evident that there is a need to develop an alternative tourism model that will support sustainable development. One of the alternative models of tourism development are focused on selective forms of tourism, and this paper analyzes the contribution of social entrepreneurship to the development of voluntourism in the Republic of Croatia.

Although there is great potential for the development of voluntourism products, since, on the one hand, there is a need for local communities to involve more people with volunteer preferences, and on the other, there is a growing interest of tourists for this type of holiday, the development of volunteer products in Croatia is relatively modest.

The pioneering project of raising public awareness about the possibilities of development voluntourism products in Croatia, with an emphasis on finding and connecting stakeholders who could support its development, was carried out by the MI-Split Association in cooperation with partners. The project „Open up borders for adventure and new travel opportunities” was designed for organizations operating in the field of tourism, non-profit civil society organizations and representatives of local administrative units, and implemented under the EU program on cross-border IPA component II, the Program on Cross-Border Cooperation Croatia - Montenegro 2007 - 2013, and the anticipated 
duration of the project was 18 months (from April 2016 to October 2017). The overall objective of the project was to contribute to the promotion of Croatian and Montenegrin tourist potentials as an integral tourist destination, improving the environment for the establishment of new tourism products based on sustainable development of the program area and improvement of social connections in the cross-border area. On the other hand, the specific objective of the project was to strengthen the cooperation between the public, profit and non-profit sector by developing voluntourism as an innovative and distinctive tourism product on joint tourism territory of Croatian-Montenegrin border areas.

Within the project activities, two workshops were held on volunteering management and social entrepreneurship, as well as development of voluntourism products. Also, the first Croatian Conference on Voluntourism was held on June 2nd 2017 in Dubrovnik, where the voluntourism innovations, best practices, as well as examples and ideas that resulted from the project's activities, were presented. Since one of the objectives of the project was to develop at least two pilot voluntourism products/activities in the cross-border area, three such examples were presented at the conference: Frano Vlašić (Luški puti j.d.o.o.) and Leo Žanetić (Otočki sabor) presented their idea of including tourists in volunteering efforts on the island of Korčula during the summer season, while Julija Milanović from the Animal Welfare Association in Cetinje and Željko Starčević from the Orjen Protection Agency in Herceg Novi presented ideas for voluntourism projects in Montenegro (Matošević Radić, Buljan Barbača, 2018).

Also, in recent years, projects, that have great potential to grow into voluntourism programs, are invented and implemented. For the last few years, the City of Nin has been working with volunteers (biologists and ornithologists) in the fields of 'Solana Nin', where volunteers work as educators on the European Bird Counting event, which aims to inform citizens and tourists and promote the exceptional biodiversity of the salt pans and lagoons. This area is listed in the Natura 2000 habitat, ecological network of nature protection areas for preserving endangered species and habitats. The volunteer role in bird watching involves tourists and all interested (mostly amateur) photographers who come to the lagoon to photograph the birds and then donate the created photos for the purpose of promoting the destination, which are then posted on the destination's Instagram profile (Lekić, 2017). In this way, the satisfaction of tourists and the local community is achieved, and free materials for promotional purposes are obtained, which again has the effect of increasing tourist demand.

An interesting idea for a volontourism product was developed on the island of Korčula, that has an exceptional natural and cultural-historical heritage. One of the interesting features of the island is the drywall, which, in addition to being the boundary between the land plots, is today also nominated as a cultural property of the Republic of Croatia, protected by the Ministry of Culture (Vlašić, 2017). The idea of a volunteer program was triggered by the desire to include tourism activities in the restoration of the Korčula drywall. The itinerary includes a seven-day stay, during which the volunteer tourists will have the opportunity to learn about the history and culture of the island of Korčula PAGE 34| Journal of Corporate Governance, Insurance, and Risk Management | 2020, VOL. 7, Series. 1 
through four days of hiking trips, and then actively participate in a volunteer project of construction and restoration of drywall, mosaic and various sculptures creation related to the island tradition. The project also includes cooperation with the European Ramblers Assocciation (ERA), which promotes and supports all European pedestrian paths, pedestrian walking programs, etc.

For the further development of voluntourism in Croatia, it is necessary to encourage the development of social entrepreneurship, in order to develop products that respect all dimensions of sustainable tourism development. The presented examples show that there are interested stakeholders on both the suppliers and the providers travel experience, but at least one serious intermediary of the tourism experience is still missing. Its role is crucial, since voluntourism development needs the incorporation of volunteer projects into high quality tourism products that tell the stories about the locals, cultural heritage and rich traditions of the host destination while encouraging both the sustainable development of the local community and the personal development of the voluntoutists.

\section{CONCLUSION}

This paper proposes that niche tourism products and more specifically, voluntourism projects, under the prism of social entrepreneurship, can become the means towards Croatian product diversification and long-term environmental, social and economic sustainability. Moreover, this paper demonstrated the connection between social entrepreneurship and volutourism and proposed a relatively coarse framework that integrates the effects of voluntourism and social entrepreneurship, through innovative products and procedures, thus affecting the sustainable development of local community through its environmental, social and economic dimension.

This research, in regard to theoretical contribution, has connected the literatures on social entrepreneurship, voluntourism and sustainable development of the local community, thus explaining the conceptual linkage between them. On the other hand, this paper offers practical implications that make contributions to the voluntourism literature, since the lack of implementation of this concept.

The focus was on the Croatian context and results indicate that there are limited number of projects concerning social entrepreneurship in voluntourism in Croatia and also that discussed projects are not recognized or there is a lack of awareness of them. The empirical work was exploratory because of the novelty of the subject and limitations related to data availability. Research assessed the situation in Croatia and although it was comprehensive under mentioned conditions, it cannot speak to social entrepreneurship in voluntourism globally, but it can offer foundation for future research in this area.

\section{REFERENCES}

Aas, Ch, Ladkin, A, Fletcher, J. 2005. Stakeholder collaboration and heritage management, Annals of Tourism Research, 32(1): 28-48. 
Alkier, R, Milojica, V, Roblek, V. 2017. Challenges of the social innovation in tourism, ToSEE Tourism in Southern and Eastern Europe, 4: 1-13.

Aquino, R S, Heike, M L, Schänzel, A. 2018. A conceptual framework of tourism social entrepreneurship for sustainable community development, Journal of Hospitality and Tourism Management, 37: 23-32.

Austin, J, Stevenson, H, Wei-Skillern, J. 2006. Social and commercial entrepreneurship: Same, different, or both?, Entrepreneurship: Theory \& Practice Journal, 30(1): 1-22.

Bacq, S, Janssen, F. 2011. The multiple faces of entrepreneurship: A review of definitional issues based on geographical and thematic criteria, Entrepreneurship \& Regional Development, 23(5-6): 373 -403 .

Brinckerhoff, P C. 2000. Social Entrepreneurship: the Art of Mission-based Venture Development. Wiley: New York.

Butcher, J, Smith, P. 2010. 'Making a Difference': Volunteer Tourism and Development, Tourism Recreation Research, 35(1): 27-36.

Croatian Bureau of Statistics. 2019. CBS Databases, Statistical Databases, Tourism https://www.dzs.hr/default_e.htm [29 December 2019].

Dacin, P A, Dacin, M T, Matear, M. 2010. Social entrepreneurship: Why we don't need a new theory and how we move forward from here, Academy of Management Perspectives, 24(3): 37-57.

Day, J, Mody, M. 2017. Social entrepreneurship typologies and tourism: Conceptual frameworks. In Social entrepreneurship and tourism: Philosophy and practice, Sheldon PG, Daniele R (eds.). Springer International Publishing: Cham, Switzerland; 57-80.

Dees, G. 1998. The meaning of social entrepreneurship, Stanford University: Draft Report for the Kauffman Center for Entrepreneurial Leadership, available at http://www.redalmarza.cl/ing/pdf/TheMeaningofsocialEntrepreneurship.pdf.

Defourny, J, Nyssens, M. 2010. Conceptions of Social Enterprise and Social Entrepreneurship in Europe and the United States: Convergences and Divergences. Journal of Social Entrepreneurship, 1(1): 32-53.

Defourny, J, Nyssens, M. 2014. The EMES Approach of Social Enterprise in a Comparative Perspective, in J. Defourney, L. Hulg_rd and Pestoff, V. (eds.) Social Enterprise and the Third Sector Changing European Landscapes in a Comparative Perspectives, Abingdon: Routledge, 42-66.

EMS 2014. Strategic Study on Social Economy Development in the Context of the South East Europe $2020 \quad$ Strategy, available at: http://www.emins.org/uploads/useruploads/pro-jektiEnpdf/RCC_Study-on-SE-in-SEE-Region_za-prel om.pdf.pdf

Fletcher, R, Murray Mas, I, Blanco-Romero, A, Blázquez-Salom, M. 2019. Tourism and degrowth: an emerging agenda for research and praxis, Journal of sustainable tourism, 27(12): 1745-1763.

Heitmann, S. 2010. Film Tourism Planning and Development - Questioning the Role of Stakeholders and Sustainability, Tourism and Hospitality Planning \& Development, 7(1): 31-46. 
Iorgulescu, M Ch, Răvar, A S. 2005. The contribution of social enterprises to the development of tourism. The case of Romania, Procedia Economics and Finance, 32: 672-679.

Kilipiris, F. 2005. Sustainable tourism development and local community involvement, Tourism and Hospitality Management, 11(2): 27-37.

Kotler, Ph. 2001. Marketing management, Millenium Edition, Prentice-Hall, Inc., A Pearson Education Company, New Jersey

Lekić, R. 2017. Razvoj proizvoda: od volonterskog turističkog proizvoda do volonterskog turističkog doživljaja, In Vodič za volonturistička putovanja, Inovacije u održivom turizmu, Udruga "MI"-Split https://www.volonturizam.info/images/doc/vodic.pdf [29 December 2019].

Light, P C. 2006. Reshaping social entrepreneurship. Stanford Social Innovation Review, Fall, 46-51.

Lipianin-Zontek, E, Zontek, Z. 2017. Co-operation between tourism enterprises as the source of new tourism product creation, ToSEE - Tourism in Southern and Eastern Europe, 4: 307-319.

Mair, J, Martí, I. 2006. Social entrepreneurship research: A source of explanation, prediction, and delight. Journal of World Business, 41: 36-44.

Martin, R J, Osberg, S. 2007. Social entrepreneurship: The case for a definition. Stanford Social Innovation Review, Spring, 29-39.

Matošević Radić, M, Buljan Barbača, D. 2018. Development of tourist offers through the European financing of the non-profit sector. in Proceedings of the 7th international scientific symposium "Economy of eastern Croatia - vision and growth", Osijek, Croatia

Morgan, J. 2012. Volunteer tourism: what are the benefits for international development?, The VolunTourist Newsletter, 6(2) http://www.voluntourism.org/news-studyandresearch62.htm [22 December 2019].

Mort, G S, Weerawardena, J, Carnegie, K. 2003. Social entrepreneurship: Towards conceptualisation, International Journal of Nonprofit \& Voluntary Sector Marketing, 8(1): 76-88.

Nsizwazikhona, S Ch, Nokwanda X. 2015. The role of local government to facilitate and spearhead sustainable tourism development, Problems and Perspectives in Management, 13(4): 27-31.

OECD 2005. Guidelines for Collecting and Interpreting Innovation Data, Oslo Manual-3rd edition. OECD, Luxembourg. Official Gazette 70/97,106/97, OG 88/01, 11/02

Peredo, A M, McLean, M. 2006. Social entrepreneurship: A critical review of the concept, Journal of World Business, 41: 56-65.

Pompurová, K, Marčeková, R, Šebová, Lj, Sokolová, J, Žofaj, M. 2018. Volunteer Tourism as a Sustainable Form of Tourism - The Case of Organized Events, Sustainability, 10: 1-12.

Reindrawati, D J. 2018. Social entrepreneurship in tourism: A way to involve locals in tourism development, The 2nd International Conference on Vocational Higher Education (ICVHE) 2017 "The Importance on Advancing Vocational Education to Meet Contemporary Labor Demands”, KnE Social Sciences, 173-185. 
Šimleša, D, Puđak, J, Bušljeta Tonković, A. 2019. Social Entrepreneurship in Croatia: Its Future, the Actors Database, and the Strategy // Social Entrepreneurship in South East Europe - Three Countries Analysis / Šimleša, Dražen (ur.). Zagreb: Institut društvenih znanosti Ivo Pilar, 27-44.

Strategy for the Development of Social Entrepreneurship in the Republic of Croatia 2015-2020, available at: http://www.mrms.hr.

Turker, N, Alaeddinoglu, F, Can, A S. 2016. The Role of Stakeholders in Sustainable Tourism Development in Safranbolu, Turkey. Paper presented at the 2016 International Conference on Hospitality,Leisure, Sports, and Tourism - Summer Session, Kyoto, Japan

United Nations Environment Programme (UNEP) \& World Tourism Organization (UNWTO). 2005. Making tourism more sustainable, A guide for policy makers. http://wedocs.unep.org/bitstream/handle/20.500.11822/8741/-

Making\%20Tourism\%20More\%20Sustainable_\%20A\%20Guide\%20for\%20Policy\%20Makers2005445.pdf?sequence=3\&isAllowed=y [16 December 2019].

United Nations World Tourism Organization (UNWTO). 2019. World tourism highlights 2018. https://www.e-unwto.org/doi/pdf/10.18111/9789284421152 [16 December 2019].

Verardi, C. 2013. Perceptions of Voluntourism, A thesis submitted to the Faculty of Graduate and Postdoctoral Affairs, Carleton University, Ottawa, Ontario

Vlašić, F. 2017. Prijedlog volonturističkog programa-Korčula, presented at the conference Volonturizam - spoj volonterstva i turizma u razvoju zajedničkog prekograničnog turističkog prostora, Dubrovnik, Croatia.

Wearing, S, McGehee, N G. 2013. Volunteer tourism: A review, Tourism Management, 38: 120-130. Weerawardena, J, Mort, G S. 2006. Investigating social entrepreneurship: A multidimensional model, Journal of World Business, 41(1): 21-35.

Williams, D A, Kadamawe, A K. 2012. The dark side of social entrepreneurship, International Journal of Entrepreneurship, 16: 63-77.

Zahra, S A, Gedajlovic, E, Neubaum, D O, Shulman, J M. 2009. A typology of social entrepreneurs: Motives, search processes and ethical challenges, Journal of Business Venturing, 24(5): 519-532. 